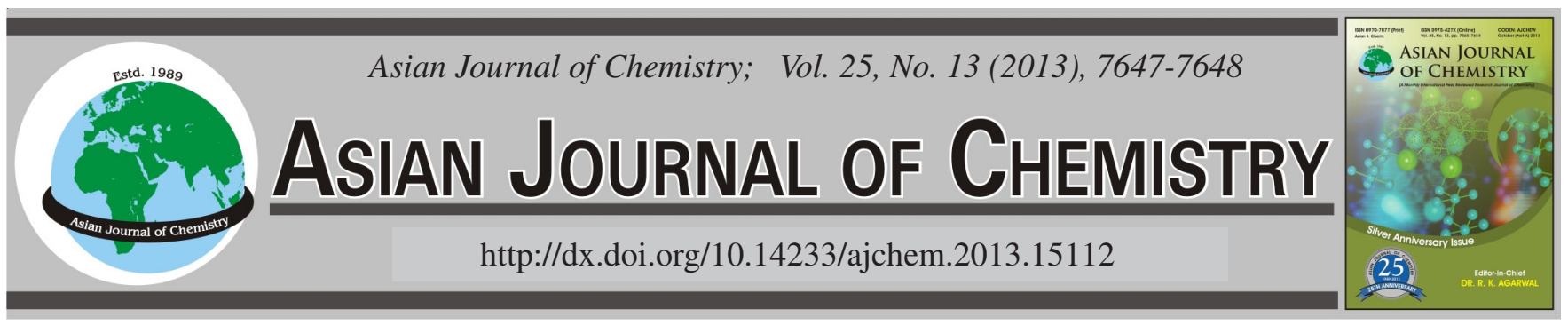

NOTE

\title{
A Novel Four-Component Reaction Between a Secondary Amine and Salicylaldehyde with Isocyanide in Water
}

\author{
F. Gharakhani ${ }^{1}$, E. Vessally ${ }^{2, *}$, A. Mohammadi ${ }^{2}$ and Z. Alimadadi ${ }^{3}$
}

${ }^{1}$ Department of Chemistry, Miyaneh Branch, Islamic Azad University, Miyaneh, Iran

${ }^{2}$ Payame Noor University, Iran

${ }^{3}$ Department of Chemistry, Tabriz Branch, Islamic Azad University, Tabriz, Iran

*Corresponding author: E-mail: vessally@yahoo.com

(Received: 9 January 2013;

Accepted: 5 July 2013)

AJC-13777

Reaction of isocyanide with iminium ion intermediate, formed by reaction between an electron deficit salicylaldehyde and a secondary amine in the presence of water proceeds smoothly at room temperature to afford benzo[b]furan derivatives (7) in high yields.

Key Words: Benzo[b]furan derivatives, Three-component reaction, Ugi reaction.

Multi-component reactions (MCRs) have attracted significant attention in the combinatorial chemistry ${ }^{1}$. Of pivotal importance in this area are the isocyanide-based multi-component reactions such as the Ugi reaction and Passerini reaction ${ }^{1-4}$. The ability of isocyanides to undergo facile addition with a nucleophile and an electrophile under mild conditions which makes them useful reactants for the development of novel multi-component reactions $s^{2,5}$. Isocyanides ${ }^{6}$, regarded as compounds with unpleasant odor and very few chemical and pharmaceutical applications while are now looked upon as useful synthons with interesting chemical properties. This change in attitude can be attributed primarily to the renaissance of isocyanide-based multi-component reactions ${ }^{7,8}$, for example, the Passerini three-component reaction (P-3CR $)^{9,10}$ and more importantly, the Ugi four-component reaction (U-4CR) ${ }^{11,12}$, with their ability to deliver a wide variety ${ }^{13}$ of the peptide analogs and heterocyclic compounds for investigation in the drug discovery programs. The well-known Ugi four-component condensation between the aldehydes, isocyanides and ammonium formate afford $\mathrm{N}$-substituted 2-formylaminocarboxamides $^{14,15}$. In this work, the reaction between salicylaldehyde, isocyanide and an amine under Ugi four-component condensation conditions affords benzo[b]furan derivative in high yields ${ }^{16}$.

Benzo[b]furan derivatives 7 were prepared based on the reported procedures. Other starting materials and solvents were prepared from Merck (Germany) and Fluka (Switzerland) and were used without further purification. The methods used to follow and monitored the reactions are TLC and NMR. TLC and NMR indicated that there is no side product. Melting points were measured on an Electrothermal 9100 apparatus and are uncorrected. IR spectra were measured on a Perkin-Elmer RXI, FT-IR spectrometer. ${ }^{1} \mathrm{H}$ and ${ }^{13} \mathrm{C}$ NMR spectra $\left(\mathrm{CDCl}_{3}\right)$ were recorded on a Bruker Avance spectrometer at 250.0 $\mathrm{MHz}$. Elemental analyses were performed using a Perkin-Elmer 2400(II) CHN/O analyzer. Mass spectra were recorded on a FINNIGAN-MATT 8430 mass spectrometer operating at an ionization potential of $20 \mathrm{eV}$. The flash column chromatography was used for further purifications from Merck silica gel powder.

Synthesis of N,N-Dibenzyl-N-[5-nitro-2-(1,1,3,3-tetramethyl-butylamino))-1-benzofuran-3-yl]amine (7): A mixture of dibenzylamine $(0.19 \mathrm{~mL}, 1 \mathrm{mmol})$ and 2-hydroxy-5nitrobenzaldehyde $(0.167 \mathrm{~g}, 1 \mathrm{mmol})$ in water $(5 \mathrm{~mL})$ was stirred at the room temperature for $1 \mathrm{~h}$. To this mixture, $1,1,3,3$ tetramethylbutyl isocyanide $(0.17 \mathrm{~mL}, 1 \mathrm{mmol})$ at $15^{\circ} \mathrm{C}$ was added rapidly and the solution was allowed to stand for $24 \mathrm{~h}$ at room temperature. The solvent was removed under reduced pressure. The flash column chromatography of the residue was carried out by using petroleum ether-diethyl ether (10:1) as eluent which gave 7 as a red viscous oil. Yield: $98 \%$. IR ( $\mathrm{KBr}$, $\left.v_{\max }, \mathrm{cm}^{-1}\right): 3400(\mathrm{NH}), 1646,1530,1476,1346,1223 .{ }^{1} \mathrm{H} \mathrm{NMR}$ $\left(250 \mathrm{MHz}, \mathrm{CDCl}_{3}\right) \delta_{\mathrm{H}}: 0.96\left(9 \mathrm{H}, \mathrm{s}, \mathrm{CMe}_{3}\right), 1.06(6 \mathrm{H}, \mathrm{s}$, $\left.\mathrm{CMe}_{2} \mathrm{NH}\right), 1.47\left(2 \mathrm{H}, \mathrm{s}, \mathrm{CH}_{2} \mathrm{CMe}_{3}\right), 4.20$ (4H, s, $2 \mathrm{CH}_{2}$, benzyl), $4.10\left(1 \mathrm{H}, \mathrm{s}, \mathrm{NH}\right.$, exchanged by $\mathrm{D}_{2} \mathrm{O}$ addition), 7.20-7.39 $(11 \mathrm{H}$, $\mathrm{m}, \mathrm{H}-\mathrm{Ar}), 7.89\left(1 \mathrm{H}, \mathrm{dd},{ }^{3} J_{\mathrm{HH}}=6.5 \mathrm{~Hz},{ }^{4} J_{\mathrm{HH}}=2.3 \mathrm{~Hz}, \mathrm{H}-4\right.$, benzofuran), $8.15\left(1 \mathrm{H}, \mathrm{d},{ }^{4} \mathrm{~J}_{\mathrm{HH}}=2.3 \mathrm{~Hz}, \mathrm{H}-6\right.$, benzofuran). ${ }^{13} \mathrm{C}$ $\operatorname{NMR}\left(62.5 \mathrm{MHz}, \mathrm{CDCl}_{3}\right) \delta_{\mathrm{C}}: 30.03\left(2 \mathrm{CH}_{3}\right.$ of $\left.\mathrm{CMe}_{2} \mathrm{NH}\right), 31.55$ 
$\left(3 \mathrm{CH}_{3}, \mathrm{CMe}_{3}\right), 31.64\left(\mathrm{C}, \mathrm{CMe}_{3}\right), 54.21\left(\mathrm{CH}_{2}, \mathrm{CH}_{2} \mathrm{CMe}_{3}\right), 56.01$

$\left(\mathrm{C}, \mathrm{CMe}_{2} \mathrm{NH}\right), 58.91\left(2 \mathrm{CH}_{2}\right.$, benzyl $), 109.87,111.50,128.74$

(3CH, benzofuran), 103.64, 114.93, 151.95, 158.32 (4C, benzofuran), $143.91\left(\mathrm{C}\left(\mathrm{NO}_{2}\right)\right), 127.34,128.60,129.18(10$ $\mathrm{CH}), 138.96$ (2C $\left.\mathrm{C}_{\mathrm{ipso}}\right)$.

As part of our ongoing program to develop the efficient and robust methods for the preparation of the heterocyclic compounds ${ }^{17}$, we report here a simple, one-pot, four-component reaction between isocyanide $\mathbf{4}$, secondary amine $\mathbf{2}$ and an electron-poor salicylaldehyde $\mathbf{1}$ in water at ambient temperature, leading to benzo[b]furan derivatives (7) (Scheme-I). We also used N-benzyl-tert-butylamine in this reaction, but the yields of the corresponding products 7 were very low and several by-products were observed (based on TLC). The reaction proceeded efficiently with electron-withdrawing 2-hydroxybenzaldehyde in water. The high yields of 7 can be explained by the greater electrophilicity of carbonyl groups of electron-withdrawing 2-hydroxybenzaldehyde derivatives relative to the carbonyl groups of electron-releasing 2-hydroxybenzaldehyde derivatives.<smiles>[X]c1ccc(O)c(C=O)c1</smiles>

(1)

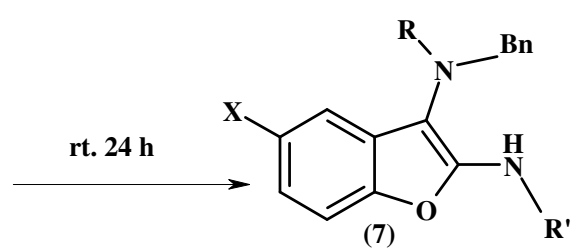

Scheme-I: Four-component synthesis of benzo[b]furan derivatives 7 in water

The structures of compound 7 were deduced from their IR and high-field ${ }^{1} \mathrm{H}$ and ${ }^{13} \mathrm{C}$ NMR spectra. For example, the IR spectrum of 7 showed a strong absorption at $3400 \mathrm{~cm}^{-1}$ indicating the presence of an amine. The ${ }^{1} \mathrm{H}$ NMR spectrum of 7 consisted of one singlet for the methyl groups $\left(-\mathrm{CMe}_{3}, \delta\right.$ $=1.12)$, one singlet for the two methylenes $\left(2 \mathrm{CH}_{2}\right.$ of two benzyls, $\delta=4.20)$, an amine hydrogen atom $(\delta=4.10)$ which was exchangeable with $\mathrm{D}_{2} \mathrm{O}$, a multiplet for the aromatic protons $(\delta=7.20-7.39)$, one doublet of doublets for the aromatic benzo[b]furan $[\mathrm{C}-4(\mathrm{H})]$ proton $\left(\delta=7.89,{ }^{3} J_{\mathrm{HH}}=6.5 \mathrm{~Hz},{ }^{4} J_{\mathrm{HH}}=\right.$ $2.3 \mathrm{~Hz})$ and a doublet for the aromatic benzo[b]furan $[\mathrm{C}-6(\mathrm{H})]$ proton $\left(\delta=8.15,{ }^{4} J_{\mathrm{HH}}=2.3 \mathrm{~Hz}\right)$. The ${ }^{1} \mathrm{H}$ decoupled ${ }^{13} \mathrm{C}$ NMR spectrum of 7 showed 15 distinct resonances.
Although we have not established the mechanism of the reaction in an experimental manner, a plausible reaction sequence that accounts for the formation of 7 was shown in Scheme-II. Thus condensation of 2-hydroxybenzaldehyde derivative $\mathbf{1}$ and secondary amine $\mathbf{2}$ give iminium ion intermediate $\mathbf{3}$, which reacts with the alkyl isocyanide $\mathbf{4}$ to afford intermediate $\mathbf{5}$. The cyclization of the ionic intermediate 5 leads to the benzofuran (6). Tautomerization of $\mathbf{6}$ could then lead to formation of the benzo[b]furan derivatives 7 .

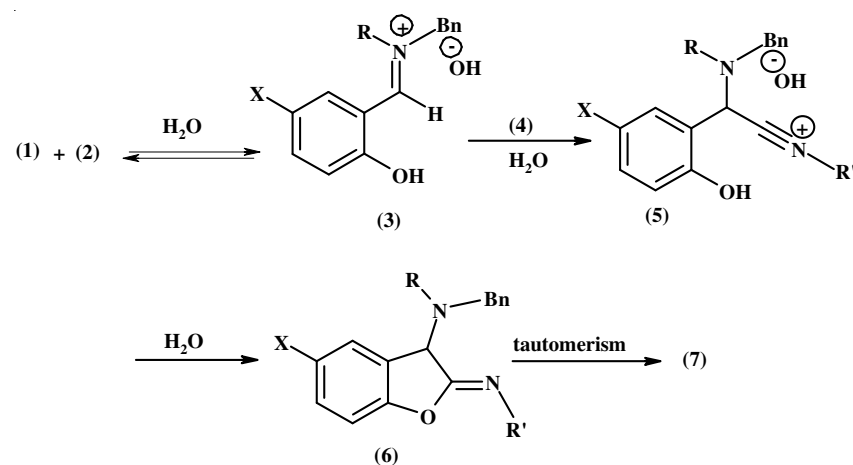

Scheme-II: Proposed mechanism for the formation of benzo[b]furan derivatives 7 in water

\section{REFERENCES}

1. I. Ugi, S. Lohberger and R. Karl, In eds.: B.M. Trost and I. Fleming, In Comprehensive Organic Synthesis, Pergamon Press: Oxford, Vol. 2, pp. 1083-1106 (1991).

2. A. Dömling and I. Ugi, Angew. Chem. Int. Ed., 39, 3169 (2000).

3. I. Ugi, Angew. Chem. Int. Ed., 21, 810 (1982).

4. A.R. Kazemizadeh and Ali Ramazani, Asian J. Chem., 23, 4613 (2011).

5. H.M. Walborsky and M.P. Periasamy, In eds.: C. Supplement, S. Patai and Z. Rappoport, In The Chemistry of Functional Groups, Wiley: New York, p. 835, Ch. 20 (1983).

6. S. Marcaccini and T. Torroba, Org. Prep. Proceed. Int., 25, 141 (1993).

7. M. Murakami, Angew. Chem. Int. Ed., 42, 718 (2003).

8. I. Ugi, S. Lohberger and R. Karl, In eds.: B.M. Trost and I. Fleming, In Comprehensive Organic Synthesis; Pergamon: New York, Vol. 2, p 1083, Ch. 4.6 (1993).

9. M. Passerini, Gazz. Chim. Ital., 51, 126 (1921).

10. M. Passerini, Gazz. Chim. Ital., 51, 181 (1921).

11. I. Ugi, R. Meyr, U. Fetzer and C. Steinbrückner, Angew. Chem., 71, 386 (1959).

12. I. Ugi and C. Steinbrückner, Angew. Chem., 72, 267 (1960).

13. R. Hoffmann, Angew. Chem. Int. Ed., 40, 3337 (2001).

14. I. Ugi and C. Steinbrückner, Chem. Ber., 94, 2802 (1961).

15. R. Bossio, S. Marcaccini and R. Pepino, Liebigs Ann. Chem., 935 (1990).

16. R. Bossio, S. Marcaccini, R. Pepino and C. Polo, Synthesis, 999 (1991).

17. E. Vessally, A. Ramazani and E. Yaaghubi, Monatsh. Chem., 142, 1143 (2011). 